\title{
The board's role in risk disclosure: an exploratory study of Italian listed state-owned enterprises
}

\author{
Alessandra Allini (corresponding author) \\ University of Naples "Federico II", \\ Economics, Management, Institutions Department \\ Via Cinthia, Montesantangelo - 80100 Naples, Italy \\ Email: alessandra.allini@unina.it \\ Tel: +39 (0) 81675080
}

Alessandra Allini is an Assistant Professor at the Univerity of Naples - Federico II

\author{
Francesca Manes Rossi \\ University of Salerno, \\ Management and Information Technology Department \\ Via Ponte Don Mellillo, 84084 Fisciano (SA), Italy \\ Email: fmanesrossi@unisa.it \\ Tel: +39 (0) 89963131
}

Francesca Manes Rossi is an Associate Professor at the University of Salerno

\author{
Khaled Hussainey \\ Plymouth Graduate School of Management \& Plymouth Business School \\ Faculty of Business \\ Cookworthy Building, Drake Circus, \\ Plymouth, Devon, PL4 8AA \\ Email: khaled.hussainey@plymouth.ac.uk \\ Tel: + 44 (0) 1752585819 \\ Fax: $+44(0) 17525585633$ \\ Khaled Hussainey is a Professor at the University of Plymouth
}




\section{Abstract}

The determinants of risk disclosure in the annual reports of listed State-Owned Enterprises (SOEs) have yet to be fully explored. The present study aims to examine the potential impact of the composition of the board of directors and company-specific features on risk disclosure levels. To this end SOEs in Italy are systematically investigated. Our findings show that diversity on the board does make a significant difference. They also lead to a number of insights that could be of use to practitioners, policy makers and standard setters.

Key words: State-Owned Enterprises, risk disclosure, corporate governance, board of directors, agency theory.

JEL: M41, H83, G32 


\section{INTRODUCTION}

Risk may be defined as any event "affecting or potentially affecting the entity's performance and financial position" (Carlon et al. 2003:38). The disclosure of risk is therefore an integral part of accountability. It is understandable in the wake of corporate catastrophes that there has been a growing amount of literature on the subject of risk management in general, while less attention has been given to risk disclosure in the public sector. In particular there is very little literature on risk disclosure in State-Owned enterprises (SOEs). In 2005 the OECD issued "Guidelines on Corporate Governance of SOEs" recommending that companies should disclose any material risk factors and measures taken to manage them.

The apparent neglect of risk disclosure in SOEs in subsequent literature is all the more surprising given the relative importance of these companies. In most OECD countries they account for a large part of GDP. They employ a considerable proportion of the population and offer essential services. Moreover, in Italy SOEs account for almost $35 \%$ of the capitalisation of the Italian Stock Exchange. They manage public money and pursue social goals that coexist with economic objectives (Calabrò et al., 2013; Hodget et al.,1996). Accountability and transparency are thus desirable not only for shareholders but also for taxpayers and other stakeholders who benefit from the SOEs services (Ferguson et al., 2002). Yet the question of disclosure by SOEs, with their complex array of interests and objectives, somehow appears to have eluded the scrutiny of scholars (Guthrie and Farneti, 2008). For years the focus on SOEs has been mainly on profit and the feasibility of privatization (Monteduro, 2014) with scant regard to risk disclosure. The scarcity of specific literature on this important aspect of SOEs is perplexing. The present study is carried out in response to calls for more research into the public sector (Grossi and Reichard, 2008).

The SOE's examined are all listed on the Italian Stock Exchange. The study draws on both Agency Theory and Signalling Theory and investigates whether or not in Italy the composition 
and characteristics of the board of directors affect risk disclosure in SOEs, and if so, in what ways.

The study, of course, has limitations, which will be examined in some detail. However its conclusions may well be of use to policy makers and standard setters concerned with the governance of the public sector when they seek to assess the strengths and weaknesses of current governance in relation to the need for greater transparency and accountability.

The remainder of the paper is structured as follows: Section 2 discusses the theoretical framework; Section 3 formulates the hypotheses; Section 4 outlines the research design; empirical findings and discussion are presented in Section 5; Section 6 takes stock of the results and points to the way ahead.

\section{THEORETICAL FRAMEWORK}

This study uses the framework of Agency Theory (Jensen and Meckling 1976) as a tool with which to explore and interpret the dilemmas inherent in the structure of governance in Italian SOEs. Agency Theory is particularly useful in that it encompasses the question factors which can affect risk disclosure in these complex companies.

In Italy SOEs have mostly come into being in their present forms as a result of either market failure or socio-political factors or a combination of both. In several instances, although the State is not the majority shareholder, it reserves the right to appoint key directors and to use what is familiarly dubbed as its "golden share" to trounce any opposition to its policies. Mixed ownership inevitably leads to the existence of multiple objectives (Peda et al., 2013). The Stateowner is called upon to manage public money in the pursuit of social goals that co-exist with economic objectives. 
Agency Theory may be used to pinpoint some of the dilemmas and contradictions inherent in Italian SOEs in terms of Principal-Principal conflict and Agent-Principal conflict.

Since the State is effectively in control of the company, private shareholders are a minority (Argento et al. 2010). The major shareholder's interest will at times be at odds with the minority's. This, in Agency Theory, constitutes a Principal-Principal conflict. There exists also a risk of appropriation of value by the majority, and an inappropriate gravitational pull on the board's decision making process (Calabrò et al., 2013).

In addition to this, there is also likely to be an Agency-Principal conflict, as the relation between citizens and the State-owner is blurred (Broadbent and Laughlin, 2003). From this perspective, the citizens who vote are the Principal, while the State shareholder is their Agent, since the latter acts on their behalf (Batley and Larbi, 2004).

Here the question of moral hazard also arises. The Agent is susceptible to the pursuit of self-interest rather than the public interest (Hinna et al., 2010; Lane, 2005). The ability of the Principal to curb opportunistic behaviour depends on how much information it has about the performance of the Agent.

This is the complex situation in which the SOE's board is required to perform multiple functions: to safeguard the public interest, to guarantee protection to stakeholders and to ensure transparency and compliance with the law (Gnan et al., 2011). In companies where the capital invested by the State comes mainly from the taxpayer, it is arguably the citizens themselves who have the greatest interest in transparent financial reporting.

Agency Theory points to greater disclosure by the board as being the way to mitigate information asymmetry and reduce moral hazard and agency costs (Verrecchia, 2001).

Greater disclosure would also enable the Principal to exercise ex-post assessment of the dual role (Agent/Principal) played by the State shareholder (Caba Perez and Lopez-Hernandez, 2009; Monfardini, 2010). 
Related to Agency Theory, Signalling Theory, formulated by Akerlof (1970) also points to greater disclosure being desirable. Elshandidy et al. (2013) argue that greater disclosure by the board signals greater ability to manage risk. The board is able to distinguish itself from others who may be perceived to manage risks less effectively. Thus risk disclosure maybe used by the board both to signal their company's good performance and to increase their legitimacy (Oliveira et al., 2011).

\section{HYPOTHESES}

Several variables have been used in disclosure studies to explore the determinants of risk disclosure, including company data and characteristics such as leverage, profitability, capitalization and corporate governance attributes, including the size of the board, its composition and its diversity (e.g. Abraham and Cox, 2007; Beretta and Bozzolan, 2004; Elshandidy and Neri, 2015; Linsley and Shrives, 2006). However, the relationship between the composition of the board and the level of risk disclosure remains under-investigated in SOEs (Allini et al., 2014).

\section{Board size}

The size of the board is perceived as a fundamental feature that affects board's effectiveness. Jensen (1993) posits that a large board may lead to less effective coordination and decision-making while the Agency Theory argues that large boards are conducive to better monitoring. Therefore, companies with large boards are more likely to disclose more information voluntarily. Although several studies have associated large boards with greater risk disclosure (Allegrini and Greco, 2013; Elshandidy and Neri, 2015), what empirical evidence there is appears to be inconclusive. Assuming that larger boards do not imply less effective governance mechanisms, we formulate the first hypothesis as follows: 
H1. SOEs with large boards have a higher level of risk disclosure

\section{Board meetings}

One of the directors' responsibilities is attending meetings. Meetings are a key factor in a board's effectiveness (Vafeas, 1999). Active boards meeting regularly are more likely to comply with their duties and enforce the monitoring of financial reporting. Furthermore, Chen et al., (2006) suggest that meeting more frequently reduces the risk of fraud. This is consistent with Agency Theory. Several studies have confirmed its positive impact on greater disclosure (i.e. Allegrini and Greco, 2013). We therefore hypothesise that:

\section{H2. SOEs with more frequent board meetings have a higher level of risk disclosure}

\section{Board characteristics}

Agency Theory reveals how board characteristics in terms of composition, diversity and expertise can affect its ability to carry out its duties (Fama and Jensen, 1983).

In particular, the presence on the board of independent directors may help to reduce information asymmetry and improve the quality of financial reporting. Independent directors are usually professional people who have neither a management role nor ties to the company through business or ownership. They have a reputation for professional integrity to protect. Prior research supports their positive association with voluntary disclosure in general (e.g. Patelli and Prencipe, 2007) and with risk disclosure in particular (Abraham and Cox, 2007; Oliveira et al., 2011). By contrast, a more recent study in the Italian setting shows no significant relation between risk disclosure and the presence of independent directors (Allini et al., 2014).

Nevertheless, as we believe that the presence of independent directors is particularly advisable in order to reduce information asymmetry and ensure a higher level of risk disclosure, we set our third hypothesis as follows: 
H3. SOEs with a higher proportion of independent directors have a higher level of risk disclosure

\section{Multiple directorships}

Agency Theory suggests a positive association between multiple boarding and effectiveness (Fama and Jensen, 1983). Previous research hypothesizes a negative impact on the monitoring role, since board members with multiple directorships would be overcommitted (Haniffa and Hudaib, 2006). The scant empirical literature on the subject provides mixed results. While Ferris et al. (2003) find no relationship, Fich and Shivdasani (2006) reveal that fewer but busier directors strengthen financial reporting quality and improve the effectiveness of corporate governance. Our study is the first to examine the impact of multiple directorships on risk disclosure in SOEs. We hypothesize that:

H4. SOEs with lower multiple directorships have a higher level of risk disclosure

\section{Board diversity}

Board diversity refers to the varying profiles that may exist amongst members of the board and how the variety may affect the decision-making process (Van der Walt and Ingley, 2003). The characteristics to be considered include: gender, age, nationality, professional experience and education.

Gender is currently the most debated diversity topic. The presence of women directors in SOEs is receiving increasing attention (Ellwood and Garcia-Lacalle, 2015). From the Agency perspective, gender would not affect effectiveness of Board. However, conventional theory does not provide insights into how women can contribute in any distinguishing or special way to the board's effectiveness. However, considering that gender may explain differences in behaviour and skills, recent literature provides mixed results. Some studies reveal that women 
directors affect board decisions positively (Adams and Ferreira 2009; Nielsen and Huse 2010). By contrast, some studies question women's ability to contribute extra value to the board (e,g. Bianco et al., 2011). Evidence regarding risk disclosure is very scarce; it includes Ntim et al. (2013), who find a positive association, and Allini et al. (2014) who find a negative association.

Nevertheless, our expectation is that board gender diversity is more likely to put pressure on directors to engage in greater risk disclosure. And so, we hypothesize that:

H5. SOEs with a higher proportion of women directors have a higher level of risk disclosure.

A further aspect related to board diversity is the educational background of its members. In the framework of the Agency Theory, diversity of educational background is perceived as ensuring better monitoring and effectiveness. Williams and O'Reilly (1998) consider both educational background and practical experience and how diversity may lead to improved disclosure. There is a scarcity of empirical evidence on the relationship between educational background and effectiveness (Güner et al., 2008). One of the few studies carried out on the subject is by Jackson (1992) who enquires whether a background in finance influences the board decision-making process. Like Jackson we believe that specific knowledge and skills in the field of accounting and finance may support board members in the decision-making process, thus increasing their quality of risk disclosure. Hence, we hypothesise that:

H6. SOEs whose boards have a larger proportion of members with an accounting/finance educational background have a higher level of risk disclosure

The age of the directors is another feature that may affect the board's performance. One would suppose mature and aged members of corporate boards to be repositories of experience. There is little evidence, however, that age diversity impacts corporate behaviour. An early study 
by Taylor (1975) shows that older directors analyse information more carefully than younger ones. By contrast, more recently, other scholars (e.g. Koufopoulos et al., 2008) have found that the higher mean age of directors provides no guarantee of contributing to greater effectiveness. While Latif et al., (2013) find that companies with younger directors perform better than those with older ones. Assuming age to be a significant feature of board diversity to be investigated, we suggest that old directors provide experience and thus increase the effectiveness of the monitoring function and improve transparency (Kang et al., 2007). We therefore hypothesise that:

H7. SOEs with a greater proportion of old directors have a higher level of risk disclosure

A number of control variables are included in order to isolate the effect of the above-mentioned determinants. We include ownership concentration, audit committee meetings, listing age, internet visibility, size, profitability and leverage, taking our cue from previous studies on the subject (Abraham and Cox, 2007; Elshandidy et al., 2013; Elshandidy and Neri, 2015; Khlif and Hussainey, 2014; Ntim et al., 2013).

\section{RESEARCH DESIGN}

The present research focuses on Italy where the State has had a strong presence amongst listed companies for several decades. The Italian government began taking over companies in financial distress in the 1930s.

In spite of the large program of privatization that began in the 1990's, there is still a considerable number of SOEs. The transformation process, which is still in progress, has 
significantly modified their ownership structure and governance mechanisms, thus increasing complexity (Grossi and Reichard, 2008).

Until 2007 there was no specific regulation of risk reporting.

In 2008, legislation was passed whereby information related to risks must be disclosed in the Management Commentary (MC) (Maffei, 2010).

This study analyses the risk disclosure in the MCs of SOEs listed on the Italian Stock Exchange (ISE) for the financial years 2008-2011.

The sample period begins in 2008 when the new requirements were introduced and ends in 2011, no further data being available after this date.

In accordance with definitions used in Italian legislation, the defining criteria of SOEs for the present study are:

1) the Government holds more than $50 \%$ of share equity or;

2) the Government holds less than $50 \%$ but more than $20 \%$ of share equity and is entitled to appoint the majority of directors on the board.

First the SOEs are identified from Datastream. They are then screened for compliance with certain criteria: the MC must be published in English; SOEs resulting from corporate combinations are excluded; delisted and newly listed ones are also excluded.

There is a total number of 22 listed SOEs in Italy. Applying the above criteria, however, we exclude one SOE with no English MC for 2008, one SOE from a corporate combination in 2010 and three other SOEs that were either delisted or newly listed in years 2008 and 2010. This leaves a total of 17 SOEs for our analysis.

Although relatively few in number, the SOEs in this sample represent almost $35 \%$ of the total ISE capitalization at the end of 2011.

To frame our dependent variable, we adopt the broad definition of risk disclosure formulated by Linsley and Shrives (2006: 398) whereby 'risk disclosure' is considered to be 
any information about "opportunity or prospect, or of any hazard, danger, harm, threat or exposure, that has already impacted or may impact upon the company, as well as the management of any such opportunity, prospect, hazard, harm, threat, or exposure".

A computer-based content analysis procedure is then used to generate the risk disclosure score (DS) following the method employed by Kravet and Muslu (2013).

The procedure is as follows.

The annual reports from 2008 to 2011 of each SOE are downloaded and converted into text format. The MC section is isolated and saved in a separate text file. Applying the method used by Kravet and Muslu (2013), three MCs per year are selected at random. All words related to 'risk' are identified and a risk-keyword list ${ }^{1}$ is compiled.

Lastly, following in the footsteps of Elshandidy et al. (2013), the NUD*IST Version Six software, developed by QSR International, is employed to identify the number of sentences which contain, at least, one risk keyword. The Risk Disclosure Score (DS) is obtained by counting the number of sentences in the MC containing one or more words from the aforementioned list on the amount of risk-keyword list.

Independent variables are measured, as described below, in accordance with the main literature on risk disclosure.

To test our hypotheses, we run the ordinary least square (OLS) regression with robust standard errors on a basis of cross-sectional analysis:

\footnotetext{
${ }^{1}$ This process helps us to identify the following English risk-keywords list: risk; risks; loss; reduce; reduction; decreased; contraction; less; lost; low; failure; failures; threat; threats; against; reverse; contrast; adverse; demoted; viable; catastrophe; catastrophic; disasters; lack; deficiency; incapable; inability; impossible; unsuitable; possibility; can; likely; uncertain; uncertainty; unsure; uncertainties; doubt; doubtful; dubious; earnings; gain; useful; challenge; challenges; opportunities; increase; increased; peak; peaks; float; floating; vary; oscillate; differ; significantly; diverge; diversify; important; symptomatic; recovery.
} 
$D S_{i, t}=\alpha_{0}+\alpha_{1}$ Boardsize $_{i, t}+\alpha_{2}$ BoardMeeting $_{i, t}+\alpha_{3}$ BoardInd $_{i, t}+\alpha_{4}$ Multipledi $_{i, t}+\alpha_{5}$ Women $_{i, t}+$ $+\alpha_{6}$ Education $_{i, t}+\alpha_{7}$ AGE $_{i, t}+\alpha_{8}$ GovOWN $_{i, t}+\alpha_{9}$ Acmeetings $_{i, t}+\alpha_{10}$ Listingage $+\alpha_{11}$ Internet $_{i, t}+$ $+\alpha_{12}$ Firmsize $_{i, t}+\alpha_{13}$ ROE $_{i, t}+\alpha_{14}$ Leverage $_{i, t}+\varepsilon_{i, t}$

where:

$D S_{i, t}=$ risk disclosure score;

$\alpha_{0}=$ the intercept;

Boardsize $_{i, t}=\mathrm{n}$. of directors on board;

BoardMeeting $_{i, t}=\mathrm{n}$. of board meetings during the year;

BoardInd $_{i, t}=$ board independence (n. of independent directors on board size);

Multipledi $r_{i, t}=$ multiple directorship (n. of other CEO commitments outside the SOE);

Women $_{i, t}=$ women on the board (n. of women directors on board size);

Education $_{i, t}=$ education of board members (n. of directors with accounting/finance degree on board size);

$A G E_{i, t}=$ average age of the board of directors (n. of directors over the mean age of board members on board size);

GovOWN $N_{i, t}=$ percentage of governmental ownership;

Acmeeting $_{i, t}=\mathrm{n}$. of audit committee meetings during the year;

Listingage $=$ average listing age of the companies;

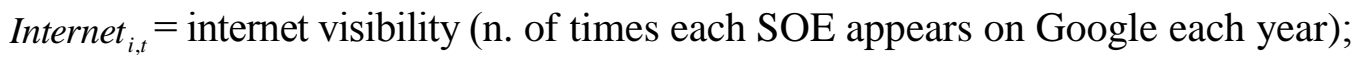

Firmsize $_{i, t}=$ Company size (n. of employees);

$R O E_{i, t}=$ return on equity;

Leverage $_{i, t}=$ leverage (debt on total assets);

$\varepsilon_{i, t}=$ standard error.

\section{Descriptive analysis}

Table 1 provides descriptive statistics. 
[Insert Table 1 here]

The results show a wide variation in the risk disclosure score (from $2.3 \%$ to $27 \%$ ), in board size (from 5 to 18 members with a mean of 10), in the number of women on boards (from 0 to $25 \%$, with a mean of $4.17 \%$ ), in CEO multiple directorships (from 0 to 12 ), in educational background, that is to say accounting and finance graduates on boards (from $20 \%$ to $77.78 \%$ ) and in the board meetings (from 1 to 20 , per year).

The mean presence of independent directors on the board is $60 \%$. The average age of the board members is 57 years old ( 48 years old for the youngest and 66 years for the oldest).

There is also a wide range of control variables. Governmental ownership varies between $30 \%$ and $88 \%$ (with a mean of $50.31 \%$ ), audit committee meetings vary from min 1 to max 21 per year, the mean listing age of SOEs is 10 years (ranging from 1 to 28 years), the number of employees ranges from 74 to 44,232 with a mean of 3,263.

Italian SOEs are highly visible on the internet, a mean of approximately 70,000 Google hits being registered each year.

Most of the SOEs are making a profit. The mean ROE is $12 \%$. There is a relatively high level of leverage, as the mean of debt on total assets ratio is $60 \%$.

Table 2 presents the Pearson correlation analyses.

[Insert Table 2 here]

There is no multi-collinearity problem because the correlations between the dependent variable and all independent variables are less than 0.70 .

\section{EMPIRICAL FINDINGS}

Table 3 shows the regression results.

[Insert Table 3 here] 
The main findings suggest that of all the variables, only board diversity significantly affects risk disclosure by SOEs.

The coefficient of the presence of women on boards is positive and statistically significant, with p-value of 5\%, suggesting that women directors improve the effectiveness of the board and enhance accountability and transparency.

This is in line with results obtained by Adams and Ferreira (2009), while it differs from Allini et al. (2014). Therefore, we accept Hypothesis 5.

Counter-intuitively and in contrast with Jackson (1992), we find a negative association between accounting/finance education and risk disclosure, since the coefficient is -0.111 , statistically significant at 5\%.

As Kang et al. reported (2007), having older directors are found to contribute to the effectiveness of the board, age being positively associated with risk disclosure, statistically significant at $10 \%$. Hence, we reject hypothesis 6 and accept hypothesis 7 .

One would expect that both seniority and educational background would have a positive impact on risk disclosure. However, the results reveal that only age has a positive impact. This suggests that older directors are more inclined to divulge information on risk and more willing to enhance transparency and to reduce information asymmetry. When considering educational background, our results are consistent with those reported by Gul and Leung (2002) indicating that graduate board directors might be aware of the consequences of risk disclosure and decide to withhold this information.

By way of contrast with previous studies on risk disclosure (e.g. Allegrini and Greco, 2013; Elshandidy and Neri, 2015; Ntim et al., 2013), our analysis shows that the remaining variables - namely board size, board meetings, board independence and multiple directorship - have no impact on risk disclosure. For control variables, in accordance with Signalling Theory, we provide evidence that internet visibility is positively associated with risk disclosure ( $\mathrm{p}$-value $1 \%$ ). 
This suggests that Italian SOEs, which are widely scrutinised by stakeholders, are subject to public demands for accountability.

Furthermore, in line with previous studies (e.g. Khlif and Hussainey 2014; Linsley and Shrives 2006), the results reveal that company size is related positively with risk disclosure. This association is significant at $5 \%$, confirming that managers of large SOEs may have greater incentive to communicate risks to distinguish their company from smaller ones (Khlif and Hussainey, 2014). In addition to this, for larger SOEs the cost of producing additional information constitutes a smaller proportion of their annual turnover, whilst small companies suffer from competitive disadvantages if they increase their disclosure levels. In contrast to previous research (e.g. Khlif and Hussainey, 2014), we find a negative association (coefficient of 0.034 ) between profitability and risk disclosure with p-value at $1 \%$. One possible interpretation is that profitable SOEs sometimes tempted to use the MC to emblazon their performance in a selfcongratulatory manner, dwelling mainly on the good news, while failing to divulge the various forms of risks. On the other hand their profitability may also be a sign that the company is operating in relatively risk-free field of activity. Finally, we do not find any association between risk disclosure and either leverage or listing age.

\section{CONCLUSIONS}

Italian listed SOEs are examined and the relationship between specific board characteristics and risk disclosure is investigated.

Agency Theory combined with the Signalling Theory is brought to bear in the formulation of several hypotheses. The most significant contribution to be derived from the results of our research is that board diversity - in terms of gender, education and age - does indeed affect risk disclosure of SOEs. We also find that company size and internet visibility are positively related, whilst profitability has a negative impact. 
This research constitutes a contribution to the international debate on determinants of risk disclosure in SOEs. Data is collected empirically in what is an under-investigated field and a response is made to the call for more research into the public domain (Grossi and Reichard, 2008).

Our paper also has several other implications. It shows that the effectiveness of governance in the practice of risk disclosure is a function of certain characteristics.

In particular the need for board diversity in SOEs should be reconsidered on account of the complexity of interests involved in their corporate governance. Namely, mechanisms related to gender, education and age diversity can offer potential benefits, while improving risk disclosure.

The Italian case may well be useful to policy makers at national and international level when they eventually review the strengths and weaknesses of current rules of public sector governance.

Our results could also offer useful insights to practitioners. If wider disclosure would improve the trust and confidence of citizens in politicians and SOEs directors, a deeper understanding of factors promoting risk disclosure would be beneficial.

Finally, our findings could be of considerable value to standard setters. Considering the recent International Framework jointly released in July 2014 by the International Federation of Accountants (IFAC) and the Chartered Institute of Public Finance and Accountancy (CIPFA) on Good Governance in the Public Sector, further specific guidelines to enhance accountability and to promote risk disclosure by SOEs are strongly desirable.

Concerning the limitations of our study, we believe that although we have considered all the Italian listed SOEs, the sample size is still relatively small. Also our sample is limited to just four years because of the availability of data at the time of starting this project.

A further weakness may lie in the fact that the $\mathrm{MC}$ is a restricted corpus and some would argue by nature tendentious, and therefore is not always the best tool to identify risks that a SOE is facing. 
However, at present this is the only source of information being offered to enable stakeholders to detect risks.

Our paper offers avenues for future research which could lead to a more extensive transnational study on the determinants of risk disclosure in listed and unlisted SOEs. Certainly the economic consequences of risk disclosure for SOEs merit further attention.

\section{REFERENCES}

Abraham, S. and Cox, P. (2007), Analysing the determinants of narrative risk information in UK FTSE 100 annual reports. The British Accounting Review, 39, 3, p.227-248.

Adams, R. and Ferreira, D. (2009), Women in the boardroom and their impact on governance and performance. Journal of Financial Economics, 94, 2, p. 291-309.

Akerlof, G. (1970) The market for 'lemons': quality uncertainty and the market mechanism. Quarterly Journal of Economics, 90, 4, p. 629-650.

Allini, A., Manes Rossi, F. and Macchioni R. (2014), Do Corporate Governance Characteristics Affect Non-Financial Risk Disclosure in Government-owned Companies? The Italian Experience. Financial reporting, 1, p. 5-31 .

Allegrini, M. and Greco, G. (2013), Corporate boards, audit committees and voluntary disclosure: evidence from Italian Listed Companies. Journal of Management \& Governance 17, 1, p.187-216.

Argento, D. Grossi, G., Tagesson, T. and Collin, S. O. (2010), The 'externalisation' of local public service delivery: Experience in Italy and Sweden. International Journal of Public Policy, $5,1, \mathrm{p} .41-56$.

Batley, R. A. and Larbi, G. A. (2004), The changing role of government: The reform of public services in developing countries, (Palgrave, Houndmills and New York):.

Bianco, M., Ciavarella, A. and Signoretti, R. (2011), Women on boards in Italy. Quaderni di Finanza, 70 p.1- 41, Rome: CONSOB.

Beretta, S. and Bozzolan, S. (2004), A framework for the analysis of risk communication. The International Journal of Accounting, 39, 3, p.265-276.

Broadbent, J. and Laughlin, R. (2003), Control and legitimization in government accountability processes: the private finance initiative in the UK. Critical Perspectives on Accounting, 14, 1-2, p.1-22.

Caba Perez, C. and Lopez-Hernandez, A.M. (2009), Governmental financial transparency in MERCOSUR member countries. International Review of Administrative Sciences, 75, 1, p.169-181.

Calabrò, A., Torchia, M. and Ranalli, F. (2013), Ownership and control in local public utilities: the Italian case. Journal of Management and Governance, 17, 4, p.835-862.

Carlon S., Loftus J. and Miller M. (2003), The challenge of risk reporting: regulatory and corporate responses, Australian Accounting Review, 13(3), p. 336-351.

Chen, G., Firth, M., Gao, D.N. and Rui, O.M. (2006), Ownership structure, corporate governance, and fraud: Evidence from China. Journal of Corporate Finance, 12, 3, p.424-448.

Elshandidy, T., Fraser, I. and Hussainey, K. (2013), Aggregated, voluntary, and mandatory risk disclosure incentives: evidence from UK FTSE all-share companies. International Review of financial Analysis, 30, p.320-333. 
Elshandidy, T. and Neri, L. (2015), Corporate Governance, Risk Disclosure Practices, and Market Liquidity: Comparative Evidence from the UK and Italy. Corporate Governance: An International Review, DOI:10.1111/corg.12095.

Ellwood, S. and Garcia-Lacalle, J. (2015), The Influence of Presence and Position of Women on the Boards of Directors: The Case of NHS Foundation Trusts. Journal of Business Ethics, DOI 10.1007/s10551-014-2206-8

Fama, E. and Jensen, M. (1983), Separation of ownership and control. Journal of Law and Economics, 26, 2, p. 301-326.

Ferguson, M.J., Lam, K.C. and Lee. G.M. (2002), Voluntary Disclosure by State owned Enterprises Listed on the Stock Exchange of Hong Kong. Journal of International Financial Management \& Accounting, 13, 2, p.125-152.

Ferris, S., Jagannathan, M. and Pritchard, A. (2003), Too busy to mind the business? Monitoring by directors with multiple board appointments. Journal of Finance, 58, 3, p.10871111.

Fich, E. and Shivdasani, A. (2006), Are busy boards effective monitors? Journal of Finance, 61, 2, p.689-724.

Gnan, L., Hinna, A., Monteduro, F. and Scarozza, D. (2011), SOEs ownership and control: Independence and competence of boards members. Corporate Ownership \& Control, 8, 1, p.720-739.

Grossi, G. and Reichard, C. (2008), Municipal corporatization in Germany and Italy. Public Administration Review, 10,5, p.597-617.

Gul, F.A. and Leung, S. (2002), Board leadership, outside directors' expertise and voluntary disclosure. Journal of Accounting and Public Policy, 23, 5, p.1-29.

Güner, B., Malmendier, U. and Geoffrey, T. (2008), Financial Expertise of Directors. Journal of Financial Economics, 88,2, p.323-54.

Guthrie, J. and Farneti, F. (2008), GRI Sustainability Reporting by Australian Public Sector Organizations. Public Money \& Management, 28,6, p.361-366.

Haniffa, R. and Hudaib, M. (2006), Corporate governance structure and performance of Malaysian listed companies. Journal of Business Finance and Accounting, 33, 7,-8 p.10341062.

Hinna, A., De Nito, E. and Mangia, G. (2010), Board of directors within public organisations: A literature review. International Journal of Business Governance and Ethics, 5, 3, p.131-156.

Hodges, R., Wright, M. and Keasey, K. (1996), Corporate governance in the public services: Concepts and issues. Public Money \& Management, 16, 2, p.7-13.

Jackson, S. E. (1992), Consequences of group composition for the interpersonal dynamics of strategic issue processing. Advances in Strategic Management ed. Shrivastava P., A. Huff and J. Dutton, p.345-382, London: JAI Press.

Jensen, M.C. and Meckling, W.H. (1976), Theory of the firm: Management behaviour, agency costs and ownership structure. Journal of Financial Economics, 3, 3, p. 305-360.

Jensen, M. C. (1993). The modern industrial revolution, exit, and the failure of internal control systems. The Journal of Finance, 48, 3, p.831-880.

Kang, H., Cheng, M. and Gray, S.J. (2007), Corporate Governance and Board Composition: diversity and independence of Australian boards. Corporate Governance 15, 2), p. 194-207.

Khlif, H. and Hussainey, K. (2014), The association between risk disclosure and firm characteristics: a meta-analysis. Journal of Risk Research, 1-31, published online. 
Koufopoulos, D., Zoumbos, V. and Argyropoulou, M. (2008), Top management team and corporate performance: a study of Greek firms. Team Performance Management, 14, 7/8, p. 340-363.

Kravet, T. and Muslu, V. (2013), Textual risk disclosures and investors' risk perceptions. Review of Accounting Studies, 18, 4, p.1088-1122.

IFAC and CIPFA (2014), International Framework: Good governance in the Public Sector. Available at http://www.ifac.org/publications-resources/international-framework-goodgovernance-public-sector

Lane, J. (2005), Public administration and public management the principal-agent perspective. (Routledge, London).

Latif, R.A., Kamardin, H., Mohd, K.N.T and. Adam, N.C (2013) Multiple directorships, board characteristics and firm performance in Malaysia. Management, 3, 2, p.105-111.

Linsley, P. and Shrives, P. (2006), Risk reporting: a study of risk disclosure in the annual reports of UK companies. The British Accounting Review, 38, 4, p.387-404.

Maffei, M. (2010), La disclosure sui rischi, con particolare riferimento alle banche, (Giappichelli, Turin).

Monfardini, P. (2010), Accountability in the new public sector: a comparative case study. International Journal of Public Sector Management, 23, 7, p.632-646.

Monteduro, F. (2014), Public-private versus public ownership and economic performance: evidence from Italian local utilities. Journal of Management and Governance, 18, 1, p.29-49.

Nielsen, S. and Huse, M. (2010), Women directors' contribution to board decision making and strategic involvement: The role of equality perception. European Management Review, 7, 1, p.16-29.

Ntim, C.G., Lindop, S. and Thomas, D.A. (2013), Corporate Governance and Risk Reporting in South Africa: A Study of Corporate Risk Disclosures in the Pre- and Post2007/2008 Global Financial Crisis Period. International Review of Financial Analysis, 30, p.363-383.

Oliveira, J., Rodrigues, L.L. and Craig, R. (2011), Risk-related disclosures by non-finance companies: Portuguese practices and disclosure characteristics. Managerial Auditing Journal, 26,9, p.817-839.

OECD (2005), Guidelines on Corporate Governance of State-Owned Enterprises, OECD Publishing.

Patelli, L. and Prencipe A. (2007), The Relationship between Voluntary Disclosure and Independent Directors in the Presence of a Dominant Shareholder. European Accounting Review, 16, 1, p.5-33.

Peda, P., Grossi, G. and Liik, M. (2013), Do ownership and size affect the performance of water utilities? Evidence from Estonian municipalities. Journal of Management and Governance, 17, 2, p.237-259.

Taylor, R.N. (1975), Age and experience as determinants of managerial information processing and decision making performance. Academy of Management Journal, 18, 1, p.7481.

Terjesen, S., Sealy, R. and Singh, V. (2009), Women directors on corporate boards: A review and research agenda? Corporate Governance: An International Review, 17: 3 p.320-337.

Vafeas, N. (1999), Board meeting frequency and firm performance. Journal of Financial Economics, 53, 1, p.113-142.

Van der Walt, N. and Ingley, C. (2003), Board dynamics and the influence of professional background, gender and ethnic diversity of directors. Corporate Governance: An International Review, 11 p.218-234. 
Verrecchia, R.E. (2001), Essays on disclosure. Journal of Accounting and Economics, 32, 1, p. 97-180.

Williams, K.Y. and O'Reilly, C.A. (1998), Demography and diversity in Organizations: A review of 40 Years of research. Research in Organizational Behaviour ed. Staw B.M. and L. L. Cummings p.77-140 (JAI Press: Greenwich).

Table 1: Descriptive analysis

\begin{tabular}{|l|c|c|c|c|}
\hline Variable & Mean & Std. Dev. & Min & Max \\
\hline Disclosure Index & 12.06 & 6.48 & 2.30 & 27 \\
\hline Board Size & 10 & 2.72 & 5 & 18 \\
\hline BoardMeetings & 11.47 & 3.94 & 1 & 20 \\
\hline BoardInd & 60 & 18.68 & 30 & 100 \\
\hline
\end{tabular}




\begin{tabular}{|l|c|c|c|c|} 
Multipledir & 2.69 & 2.13 & 0 & 12 \\
\hline Women & 4.17 & 6.57 & 0 & 25 \\
\hline Education & 50.85 & 14.95 & 20 & 77.78 \\
\hline Age & 57 & 3.82 & 48 & 66 \\
\hline Control variables & \multicolumn{4}{|l}{} \\
\hline GovOwn & 50.31 & 14.42 & 30 & 88 \\
\hline Acmeetings & 8.21 & 4.87 & 1 & 21 \\
\hline Listing age & 10 & 6 & 1 & 28 \\
\hline Internet & 69,354 & 145,020 & 671 & $1,000,000$ \\
\hline Firmsize & 3,263 & 7,437 & 74 & 44,232 \\
\hline ROE & 12 & 41 & -28 & 344 \\
\hline Leverage & 60 & 13 & 21 & 96 \\
\hline
\end{tabular}

Table 2: Pearson correlation analysis

\begin{tabular}{|c|c|c|c|c|c|c|c|c|c|c|c|c|c|c|c|}
\hline Variable & 1 & 2 & 3 & 4 & 5 & 6 & 7 & 8 & 9 & 10 & 11 & 12 & 13 & 14 & 15 \\
\hline 1. indextext & 1 & & & & & & & & & & & & & & \\
\hline 2. GoveOwn & 0.02 & 1 & & & & & & & & & & & & & \\
\hline 3. Firmsize & -0.02 & -0.42 & 1 & & & & & & & & & & & & \\
\hline
\end{tabular}




\begin{tabular}{|c|c|c|c|c|c|c|c|c|c|c|c|c|c|c|c|}
\hline 4. Listingage & -0.03 & -0.36 & 0.44 & 1 & & & & & & & & & & & \\
\hline 5.Internet & 0.04 & -0.29 & 0.14 & 0.24 & 1 & & & & & & & & & & \\
\hline 6. Boardsize & -0.01 & 0.08 & 0.08 & 0.06 & 0.11 & 1 & & & & & & & & & \\
\hline 7. Boardind & -0.01 & -0.02 & 0.21 & 0.22 & 0.17 & 0.50 & 1 & & & & & & & & \\
\hline 8. Women & 0.16 & 0.21 & -0.11 & 0.18 & -0.03 & 0.14 & 0.01 & 1 & & & & & & & \\
\hline 9. Education & -0.12 & -0.44 & 0.27 & 0.17 & 0.13 & -0.21 & 0.22 & -0.50 & 1 & & & & & & \\
\hline 10. Multipledir & 0.08 & 0.05 & -0.08 & -0.43 & -0.12 & -0.29 & -0.32 & -0.18 & -0.13 & 1 & & & & & \\
\hline 11. Age & 0.17 & -0.37 & -0.08 & 0.18 & 0.30 & 0.21 & -0.04 & -0.11 & 0.04 & 0.15 & 1 & & & & \\
\hline 12.BoardMeetings & 0.02 & -0.25 & 0.01 & -0.05 & 0.27 & -0.16 & 0.16 & -0.41 & 0.34 & 0.03 & -0.01 & 1 & & & \\
\hline 13. Acmeetings & 0.12 & -0.34 & $\mathbf{0 . 5 3}$ & 0.17 & 0.38 & -0.15 & 0.21 & -0.27 & 0.41 & 0.15 & -0.04 & 0.45 & 1 & & \\
\hline 14. $\mathrm{ROE}$ & 0.00 & -0.01 & 0.28 & 0.05 & 0.04 & 0.31 & 0.22 & 0.11 & -0.03 & -0.12 & 0.02 & 0.01 & 0.03 & 1 & \\
\hline 15. Leverage & -0.11 & -0.11 & 0.22 & -0.06 & 0.19 & 0.32 & 0.30 & -0.10 & 0.12 & -0.27 & 0.03 & 0.00 & 0.08 & 0.16 & 1 \\
\hline
\end{tabular}

Bold numbers indicate that the correlations between the variables are statistically significant. 
Table 3: Regression analysis

\begin{tabular}{|c|c|c|c|c|}
\hline Variables & Coef. & Std. Err. & $\mathbf{t}$ & p-value \\
\hline Boardsize & -0.004 & 0.003 & -1.15 & 0.256 \\
\hline Boardmeetings & 0.002 & 0.002 & 0.84 & 0.407 \\
\hline BoardInd & -0.009 & 0.051 & -0.02 & 0.987 \\
\hline Multipledir & -0.051 & 0.042 & -1.20 & 0.237 \\
\hline Women & 0.2684 & 0.141 & 1.90 & $0.050 * *$ \\
\hline Education & -0.111 & 0.056 & -1.98 & $0.050 * *$ \\
\hline Age & 0.2670 & 0.148 & 1.80 & $0.078^{*}$ \\
\hline GoveOwn & 0.0179 & 0.061 & 0.29 & 0.770 \\
\hline Acmeetings & -0.001 & 0.002 & -0.12 & 0.904 \\
\hline Listing age & -0.002 & 0.002 & -1.27 & 0.210 \\
\hline Internet & 0.017 & 0.005 & 3.01 & $0.004 * * *$ \\
\hline Firmsize & 0.013 & 0.007 & 1.98 & $0.050 * *$ \\
\hline ROE & -0.034 & 0.009 & -3.82 & $0.000 * * *$ \\
\hline Leverage & -0.035 & 0.067 & -0.52 & 0.603 \\
\hline cons & -0.857 & 0.586 & -1.46 & 0.150 \\
\hline R2 & 0.755 & & & \\
\hline $\mathrm{F}$ & 13.670 & & & \\
\hline Observations & 68 SOES & & & \\
\hline
\end{tabular}

Correlation is significant *at the 0.1 level; ${ }^{* *}$ at the 0.05 level, ${ }^{* * *}$ at the 0.01 level. 